\title{
Promoting a Community of Inquiry in a Civics and Citizenship Education Class through the Pedagogy of Philosophical Inquiry
}

\author{
Suhailah Hussien \\ Kulliyyah of Education, \\ International Islamic University Malaysia, \\ Kuala Lumpur, Malaysia \\ suhailah@iium.edu.my
}

\author{
Nazatul Akmar Mokhtar \\ Kulliyyah of Education, \\ International Islamic University Malaysia, \\ Kuala Lumpur, Malaysia \\ nazatulakmar@iium.edu.my
}

\author{
Rosnani Hashim \\ Kulliyyah of Education, \\ International Islamic University Malaysia, \\ Kuala Lumpur, Malaysia \\ rosnanih@gmail.com
}

\begin{abstract}
In realising the development of ethics and values among Malaysian school-going students, depicted in Shift 3 Aspirations of the Malaysian Educational Blueprint 2013-3025, the study examined how the pedagogy of philosophical inquiry helped in the development of a community of inquiry (CI) in the Civics and Citizenship Education classroom. The study employed a qualitative action research design, where the researcher used the observational method, which is based on the Lipman's CI checklist, to identify seven elements of CI in the classroom; namely, participation, quest for meaning, shared cognition, challenging as a procedure, deliberation, impartiality and thinking for oneself. Findings of the study showed that the philosophical inquiry pedagogy and the community of inquiry assisted in the effective teaching of CCE as students discovered a more meaningful learning experience, became more empowered in their thinking and views, and more sensitive to the current issues, paving the way to become good citizens of the nation.
\end{abstract}

Keywords: Civics and Citizenship Education, Community of Inquiry, Philosophical Inquiry, student empowerment, meaningful learning

\section{INTRODUCTION}

In September 2013, The Ministry of Education launched the new Malaysia Education Blueprint (MEB) 2013 - 2025, which entails the transformation of the Malaysian school curriculum from the Malaysian Integrated Curriculum (KBSR and KBSM) to the Malaysian Standard Curriculum (KSSR and KSSM). It put forth 11 strategies and operational shifts that would be required to equip our students holistically to meet the challenges of the 21 st Century. Out of the 11 shifts, Shift 3 aims to develop values-driven Malaysians through 5 System Aspirations, namely Access, Quality, Equity, Unity, and Efficiency. And among the 5 System Aspirations, 
Quality and Unity are considered most important as both aspirations outline the focus on "improving access to education, raising standards (quality), closing achievement gaps (equity), and fostering unity amongst students, and an education system that promotes shared values and experiences by encouraging students to embrace diversity" (PADU).

Meanwhile in the MEB 6 Student Aspirations, Thinking Skill, Ethics and Spirituality, and National Identity are found to be related. For Thinking Skill, it is hoped that students will engage and practise life-long learning, and be critical thinkers, reasonable, rational, creative, and innovative. The MEB acknowledges that there is a need to improve students' ability to apply knowledge and thinking critically beyond the classroom. For Ethics and Spirituality, the education system aims to inculcate strong ethics and spirituality to prepare students for future challenges, acquire strategies in conflict resolution, make sound judgments and have courage to do the right thing. In realising this, students will later contribute to the betterment of the community and nation when they become adults.

Finally, the National Identity aspires to "instil an unshakeable sense of national identity and patriotism, tied to the principles of Rukun Negara, irrespective of students' ethnicity, religion or socio-economic status" (PADU). In order to realise this, students need to have an understanding of the nation's history, a sense of inclusiveness in sharing common aspirations and embracing diversity. Some of the initiatives to realise these aspirations, are the enhancement of subjects like Islamic and Moral education with improved focus on unity to foster stronger ties among diverse students. The emphasis of students' participation in programs such as 1 Sport, 1 Club and 1 Uniformed Body, and Rancangan Integrasi Murid Untuk Perpaduan (Program for Integration of Students for Unity - RIMUP) was also highlighted in this shift (PADU).

As the year 2020 is drawing to an end, the MEB is about to enter its Third Wave (2021 2025); hence there is a need to examine the extent of success of all initiatives thus far, while planning on its improvement for better implementation in the forthcoming years. The Annual Report for 2018 highlights among others, the Course for Fostering Unity for school Principals and Headmasters, the existing Unity school programs, some new co-curricular activities, and some initiatives that had been implemented successfully. However, the report did not mention classroom-based practices that would help realise Shift 3 aspirations though the development of ethics, values and unity in schools, that were stated as priority initiatives.

Apart from Islamic and Moral Education as subjects that play an essential role in Shift 3, Civics and Citizenship Education (CCE) is also another important school subject that can help achieve Shift 3 aspirations. Generally, CCE is regarded as an important subject and compulsory to be taught in many countries. This is simply due to its aim to instill understanding of the nation's history, love for the nation, and appreciation of and respect for the diverse traditions, and culture. Unfortunately, CCE has not been receiving due attention by parents, students and even teachers (Bandu, Awang \& Ahmad, 2017; Hashim, Hussien \& Juperi, 2014). It was reported that the lack of interest in the subject and poor pedagogical approach will only make CCE lose its importance in the education system, despite it being a subject that is recognized and emphasized by many developed countries (Mahmood, 2014). The absence of an effective classroom pedagogy may hinder the efforts of fostering unity among the multiethnic students, 
as aspired by the MEB. In addition, the Minister of Education announced the change of delivery for CCE on August 13, 2019. Instead of CCE being taught as a stand-alone subject, it is to be integrated in five subjects namely, Malay Language, English Language, Islamic Education, Moral Education and History. The CCE module will also be implemented in the school assembly and co-curricular activities (Malay Mail, 2019).

In view of this change, there is a need to identify an appropriate pedagogy that can fulfill the aims and objectives of CCE while it is integrated in these subjects. Teaching a subject such as CCE that is geared towards the promotion of values so that students may understand, reason and act upon them requires a pedagogy that can help realise these aims. In this regard, inquirybased learning has been viewed as an appropriate pedagogy that offers students a meaningful learning experience through the process of discovery method. Several studies have shown that the inquiry-based learning in different subjects and levels of education has led to more independent, meaningful learning and improved critical thinking and reasoning skills (Ghaemi, 2017; Smallhorn, Young, Hunter \& Burke da Silva, 2015; Sriarunrasmee, Suwannatthachote, Dachakupt, 2015).

Among the many types of inquiry-based learning, one particular pedagogy stood out, i.e. the Hikmah pedagogy, a pedagogy of philosophical inquiry since some studies have found that it is effective in the teaching of concepts and values, such as Islamic Education, Moral Education and CCE (Hashim et. al, 2014; Hussien, Hashim and Mohd. Mokhtar, 2017; Preece \& Juhasni, 2015; Zulkifli, 2018, 2019). Therefore, this paper aims to present how a pedagogy of philosophical inquiry has helped to develop a community of philosophical inquiry in a CCE classroom for student empowerment and meaningful learning experience. The development of a community of inquiry can assist in the development of ethics and values as aspired in Shift 3 of the MEB.

\section{Philosophical Inquiry and Community of Inquiry}

Civics and Citizenship Education (CCE) can both be taught and learnt through formal and informal learning. The common aims of developing individuals who are ethical and responsible towards oneself and society can be materialized through conscious and unconscious efforts. Although CCE is considered as an important subject by many countries in the world, the structure, content and pedagogy of CCE may differ. The western version may be 'fundamentally political', while the eastern content is more 'relationalistic' (Lee, 2011, p. 336). Lee further explained that many Asian citizenship education teachers are merely transmitting knowledge of good citizenship and inculcating the desired values to produce the next generation that can fit into the established social and value system. However, if we are concerned with the success of CCE, then there is a need to emphasise on inquiry habits, and skills of making good decisions and resolving conflicts. This will promote the development of students who will eventually become active citizens and can contribute effectively to the development of the nation. Thus, discussions held in CCE classroom should encourage open-mindedness and require critical and analytical thinking instead of discussing less controversial matters. This is achievable if inquiry-based pedagogy is used to teach students in a CCE classroom. Through inquiry-based pedagogy, CCE classroom will provide the space for students to discuss and have 
critical dialogues on various current topics and issues that would help them to become better citizens (Alivernini, \& Marganelli, 2011; Schulz, Fraillon, Ainley, Losito, \& Kerr, 2008; Torney-Purta, Richardson, \& Barber, 2009). Engaging in such dialogues will lead to the construction of students' ethnic and national identity by connecting to the nation's history and culture (Peck, 2009). This will also move them to actively participate in the community, playing their role as good citizens.

How does an inquiry-based pedagogy help to realise the aims of CCE? Inquiry-based pedagogy is derived from the constructivist theory of learning. Vygotsky (1978), a prominent social constructivist, introduced the concept of the Zone of Proximal Development (ZPD), where a child can reach a better stage of doing something and later be able to do it independently if he is being assisted. He further explains that a child needs to be involved in a collaborative task, while interacting with his peers and the teacher. In this regard, philosophical inquiry can be considered as a type of learning that helps students to construct their own meanings of concepts. Based on the theory of constructivism, philosophical inquiry approach replaces the teacher's control of students' learning and shift it to students' empowerment. However, a teacher's role remains crucial in supporting meaning-making and challenging the existing idea. As a result, learning becomes an active process where knowledge is constructed rather than transmitted.

The Philosophical inquiry (PI) approach is also based on Dewey's (1972) idea that knowledge is the product of continuous interaction with the environment. Dewey (1933) also identifies open-mindedness, intellectual responsibility and wholeheartedness, as pre-requisites for reflective thinking and inquiry habits. This act of metacognition makes a child an active participant who interacts with his environment and reality to construct meaningful knowledge. For Dewey (1972), it is the constant process of evaluating or thinking that is important if not more important, than the outcome. The true meaning of education, for Dewey, is when there is interaction in a social setting, with people exchanging experiences and contributing to one another's, with the process of reflection taking place. Dewey (1960) stressed on communal and self-correcting inquiry as an essential process of learning, which is the skeleton of democratic practices. It is therefore very crucial for schools to provide such encouraging atmosphere as a conducive setting for the process of learning. Within the community of inquiry, interaction is ongoing and actively done whether through the expression of own ideas verbally, or mulling over others' ideas in silence. It also recognizes students as equal contributors to knowledge, as teachers or rather facilitators are learning from them, too.

Both Vygotsky and Dewey acknowledge the potential or learning ability of students, which can be further enhanced with the help from, and interaction with the environment and the society. A social setting can encourage meaningful communication through questioning and discussions. It is also a platform which scaffolds further development of a student's potential as he is encouraged or challenged to reflect on the ideas given. By using the PI approach, students are given the opportunities to question, discuss and reflect on civic values and knowledge instead of merely accepting them as accumulated information.

The idea of PI approach was introduced in the 1980s by Lipman in his program, Philosophy for Children (P4C). Many studies have been done to demonstrate the effectiveness 
of the program to the extent that the UNESCO High-level Meeting of Asian, Pacific and Australasian educators in Manila supported its implementation in May 2009 (UNESCO, 2009). Any subject teachers within any given timetable can use this in-content approach of teaching concepts and values through thinking. This pedagogy may be the answer to the question of how we teach CCE meaningfully by integrating it in an existing subject in the curriculum. It is suitable for the teaching of Civic and Citizenship Education because it enhances students' reasoning skill, which is an essential element in a democratic society. Good reasoning can help to shape better citizens and in return forms better society. It helps to facilitate self-actualization. With good reasoning, people learn to deal with moral dilemma in a new constructive way. It helps them to think beyond conditioned and stereotypic responses which will generate meaningful reaction to the real world (Splitter \& Sharp, 1995). It is also the platform for democratic discussion to discuss the society's complex problems, which are attached to complex reasons. Through dialogue, students can explore and interpret the moral dilemma with honest reflection. This will help build an ethical understanding based on students' worldview, which would lead to self-correction and student empowerment.

The main focus of PI is to develop a community of inquiry. A community of inquiry is a group of people who think together to understand and appreciate the world through the journey of philosophical exploration (Hannam \& Echeverria, 2009; Millett \& Tapper, 2012). It is a space where they can discuss critically, creatively and collaboratively on their own selective ideas and concepts which they find worth pursuing (Cam, 1995; Wilks, 1995). The elements of listening, empathy, respect, friendship, and working and thinking cooperatively are present throughout the dialogical discussion. The discussion aims to provoke deeper understanding of the complexities of the issues. In these discussions, disagreement is common and allowed, so long as it is done in a civilised manner. Everyone has the freedom to change one's mind as no authoritative idea is being imposed. When views are presented logically and members are involved in logical analysis (McCall, 2009), self-correction is what it hopes to achieve (Fisher, 2003). The teacher acts as a facilitator who must be a good listener, open-minded, and a skilful questioner who can challenge opinions and responses in order to bring the discussion to deeper and higher levels.

There are seven elements highlighted by Lipman (2003) as the practice of the community of inquiry. These are participation, quest for meaning, shared cognition, challenging as a procedure, deliberation, impartiality and thinking for oneself. To realise these elements, teachers can model their role effectively by being critically engaged in the philosophical discussions. A variety of materials or stimulus can be used to suit this student-centred approach, too. Although each session has its own time frame, it is essential for students to feel that in seeking understanding of an issue, time has no boundary. In fact, students are not obliged to find the solution at the end of every lesson. Instead, the discussion can be expanded after the teaching period has ended, with the aim that members of the community of inquiry will further discuss the issue publicly or privately. It can be done during their informal conversation with others or by reflecting personally within themselves. Good time management is not about finishing the discussion on time. It is about having a good classroom interaction, even if it is done within a limited time, to spark continuous discussion among them. More importantly, when such discussions are extended beyond the classroom into their daily life, this indicates that they have experienced meaningful learning. Given the potential of the philosophical 
inquiry, the study presents how the pedagogy has transformed students of a CCE class into a community of inquiry.

\section{METHODOLOGY}

\section{Research Design}

The research design employed was an action research of a case of a Malaysian secondary school involving a CCE classroom. The paper discusses a small part of the larger scale study and only focused on the development of the community of inquiry in the CCE class through the use of philosophical inquiry pedagogy. One of the researchers taught the CCE class involving 25 students for one year. Permission to teach and conduct the action research was gained from the school principal, class and CCE subject teachers, and the students. The researcher selected relevant materials and stimuli relevant to the CCE syllabus with the aim to trigger critical discussions in the class. The researcher used classroom observation, guided by the checklist of Community of Inquiry (CI) (Lipman, 2003) elements presented in Table 1.

\section{Table 1}

Checklist on the Community of Inquiry elements

\begin{tabular}{|c|c|}
\hline Elements & Examples: Are the students able to: \\
\hline Participation & $\begin{array}{l}\text { listen to others? } \\
\text { express themselves (verbally and non-verbally) } \\
\text { articulate their agreement or disagreement? } \\
\text { answer question individually and in group? } \\
\text { trust the facilitator? } \\
\text { trust each other? }\end{array}$ \\
\hline $\begin{array}{l}\text { Shared } \\
\text { cognition }\end{array}$ & $\begin{array}{l}\text { take turns to say something? } \\
\text { let others finish their sentences? } \\
\text { stick to the point? } \\
\text { offer creative and unique solution? }\end{array}$ \\
\hline $\begin{array}{l}\text { The quest for } \\
\text { meaning }\end{array}$ & $\begin{array}{l}\text { ask questions? } \\
\text { ask their friends questions voluntarily? } \\
\text { correct each other with sensitivity? } \\
\text { express their ideas explicitly using precise words? } \\
\text { show sensitivity to context (being able to identify specific } \\
\text { characteristics which make a difference in judgement formation) }\end{array}$ \\
\hline Deliberations & $\begin{array}{l}\text { see views from multiple perspectives? } \\
\text { begin to understand the perspectives of others? }\end{array}$ \\
\hline Impartiality & $\begin{array}{l}\text { accept mistakes in their reasoning? } \\
\text { display open-mindedness? } \\
\text { accept verbally other peoples' arguments if their views are better } \\
\text { than theirs? }\end{array}$ \\
\hline
\end{tabular}


Table 1 Continued

\begin{tabular}{ll}
\hline \multicolumn{1}{c}{ Elements } & \multicolumn{1}{c}{ Examples: Are the students able to: } \\
\hline $\begin{array}{l}\text { Thinking for } \\
\text { oneself }\end{array}$ & $\begin{array}{l}\text { willingly change their minds? } \\
\text { be self-correcting of their own views? }\end{array}$ \\
$\begin{array}{ll}\text { Challenging as a } \\
\text { procedure }\end{array}$ & $\begin{array}{l}\text { still forward their argument even when the majority are of } \\
\text { opposing stance? } \\
\text { express their disagreement if they think there are weaknesses in } \\
\text { others? }\end{array}$ \\
\hline
\end{tabular}

There was a total of 46 lessons and almost all were audio recorded with a few video recordings in between. The prolonged classroom observation entailed rich data, which included both expected and unexpected events. As the classroom discourses were audio-recorded, the researcher transcribed the discourses for the purpose of analysing the CI checklist. Students were allowed to use both English and Malay language in their conversations. The selected excerpts used to present the findings were translated into English through back-to-back translation so as to ascertain its correct meaning. The researcher also employed peer debriefing, expert's review and audit trail to establish the credibility, rigour and trustworthiness of the data. Ethical issues such as confidentiality, anonymity and privacy of the students were considered where all 25 students (13 boys and 12 girls) gave their informed consent to be involved in the study. Pseudonyms were assigned to the students to ensure the protection of their identities.

\section{FINDINGS}

The case study found all seven elements of community of inquiry, as proposed by Mathew Lipman (2003), in the CCE class. These were participation, quest for meaning, shared cognition, challenging as a procedure, deliberation, impartiality and thinking for oneself.

\section{Participation}

Students' participation was observed to be increasing throughout the 46 lessons. This is evident in the lesson excerpts used to support all seven elements of community of inquiry. Participation also implies that students are not just expected to become active contributors in the discussion, but also active listeners. This is an important skill because they will need it to build on their friends' ideas and views, or even to contradict them.

In Lesson 26,

Firdaus: How are we going to give job opportunities to the fishermen when they don't have experiences and don't know how to speak English (to deal with the tourists)?

Marhah: Ok we can get them a translator.

Sadiqah: Then the translator will earn more than the fishermen.

Ariff : They can use simple sign language. 
Sadiqah: That would give trouble to the tourists. They might say, is this what I get after paying so much (students were laughing as he's demonstrating the act of using sign language)?

Rizal : How is the government going to stop the fishermen who are against this idea, they might hurt the tourist you know.

Ariff : We will make sure that all of them will agree.

Haziq : But there must be people who disagree. (Class became noisy)

Sofi : If you disagree, you can go somewhere else!

Nabillah: Ok lah, we will try to satisfy them. (Sigh)

Rizal : To accept and to give opinion are easy. What is difficult is to give advice.

Qaisara: To give opinion means to come out with good ideas. To give advice means to correct someone.

Ariff : To give opinion can be to give a bad or good idea, but to give advice it has to be something good.

Farah : To give advice means to say something about an action, and not about someone's personality.

The excerpt of Lesson 26 showed how different students participated in the discussion actively and negotiated their views when discussing how to help fishermen gain a higher income through tourism. Meanwhile, lesson 42 displayed how students participated in offering their own definitions when discussing certain concepts. Both lessons indicate that students participated actively and were keen to contribute their own ideas to the discussion. This is evident throughout all classroom discourses as presented in the subsequent lesson excerpts.

\section{Quest for Meaning}

It is important for students to identify concepts involved in trying to understand an issue. Before they can offer solutions to a problem, students need to define certain concepts through mutual understanding. Students' inquisitive mind should be explored further by allowing them to question on anything and to do it continuously. Since a community consists of people from different background, experiences and cognitive abilities, it is important that words or concepts are defined clearly before they explore any issues further.

For example, in Lesson 24, a student asked an intriguing question that made others ponder on the types of people who need help from the public.

'Can people who faced problem because of being indebted to loan shark be categorised as unfortunate people?'

In Lesson 20, students were asked to define the words challenges and test, and a student's response was:

'I feel that test is given by Allah to everyone. You need to be tested at some point of your life. That is test. But challenges is when Allah wants to see if we can go through it or not...to examine the level of our iman.' 
The two excerpts displayed students' engagement in the quest to search for meaning of certain concepts. Students' quest for meaning was not forced by the teacher, but arise from their own interest in the issue discussed. This is also highlighted by Kennedy (2012) that a community of inquiry engaging in philosophical discussions is determined to discover the meanings of concepts that they often use such as challenges, test, poverty, fairness, and justice. All these concepts are imperative in CCE and in developing students who will apply and practise the values when they become adults in their later life.

\section{Shared Cognition}

When a person is reflecting silently, he will be engaged in a series of mental acts such as wondering, defining, reasoning, supporting, opposing, and differentiating. Students experienced shared cognition with other members of the community of inquiry as exemplified in the excerpts of Lesson 21. When shared cognition becomes a habit, students may even extend it beyond the classroom. Discussions that are extended in public settings may entail various acts of questioning, giving examples, offering hypothesis, objecting, and many other verbal actions in order to solve an issue. This process involves both lower and higher-order thinking processes. The more participative the students are with various thinking processes involved, the better the CCE lessons will be.

In Lesson 21:

Sofi : We will try to make him aware by doing the same to him. Let him feel what we felt, to make him aware... We should try to advise, if he doesn't listen then we do that (to suggest)

Teacher: Haa this is another point of view. People do wrong to you, you return it to him... What is your view, Marhah? Would you do the same thing? Why? (to invite participation)

Marhah: To make him aware. (to reason)

Haziq : To me you would be on the same level as the offender because you would be doing the same thing that the offender is doing. (to disagree)

Soffi $\quad$....If he gets angry at us, then we just tell him that is what we felt when he did it to us. (to explain one's intention)

Teacher: Can't you describe verbally (your feelings) instead of doing the same thing to him? (to suggest an alternative)

Nabillah : ...You shouldn't put yourself as the same level with the loser. (to support Haziq)

Zarif : I think we can be angry but we need to let him explain first. We listen to what he has to say. The bad thing that will happen if we don't listen to him, he will also be angry with us. And when one gets angry, he will say many bad things. He might run away. (to suggest and explain)

In Lesson 21 excerpts, the researcher identified the mental acts of students' responses. The various mental acts portrayed how students were engaged in different mental acts yet contributing to the analysis of the issue to arrive at a conclusion. Striano (2011) emphasises that community members engaging in philosophical inquiry co-exist in a social and cognitive matrix as they engage in different mental acts while discovering and creating new meanings together. 


\section{Challenging as a Procedure}

To challenge one's idea is to demand for further clarification, or to ask for reasons to support the judgment. In a community of inquiry, Lipman (2003) asserts, "challenging is good but it need not be heated" (p. 197). In fact, with good communication skills, students will learn to challenge each other and view the act positively. Lesson 24 and 28 excerpts present discussions consisting of different opinions and views.

In Lesson 24:

Teacher: How do you verify whether the news is true or false? (fraud in asking for donation).

Nadrah: We just donate, if they committed fraud, then we will still be rewarded. Al : No way. If the donation is RM 10 thousand, then it will be gone just like that? (if it is a fraud)

In Lesson 28:

Amsyar: This island is a private island that not many tourists can visit.

Teacher: The government will limit the tourists.

Irfan : Teacher, but won't the government want to increase the income so, how can we do this if limited tourists are allowed?

The presented excerpts show that students' disagreements and differing views do not necessarily lead to conflict, but can be resolved amicably with the force of a better argument. This is essential to be instilled among students since they live in a multiracial country and are exposed to divergent perspectives particularly through the social media. Hence, using this approach in CCE helps to train students to challenge ideas and be ready to be challenged. This cognitive procedure is essential in students' discovery journey so that they will not merely be passive recipients of knowledge. To correct one's thought or be corrected is part and parcel of the learning process.

\section{Deliberation}

A good argument or discussion of an issue will allow students to hear the multiple reasons and alternatives to be considered. In the community of inquiry, students learn that they are not in a hurry to reach a conclusion at the end of every lesson. In fact, certain understanding of an issue will take longer than what they have expected. Through exchanging of ideas and hearing the other side of the argument, students will learn to 'weigh' the alternatives and reasons with careful consideration, before making a good judgment. This is illustrated in Lesson 17.

In Lesson 17:

Amsyar: Why are there people without property?

Sofi : Lazy or disabled. 
Alisya : Maybe he has tried his best to earn money but was not successful. Maybe Allah wants to test him.

Nabil : Maybe he did not get the opportunity to get a job. He wants it but was not gven any..

Irfan : Maybe he's a descendant of poor people. Like what Amsyar mentioned, maybe he is lazy or cannot work and this can pass to the children too... Maybe the children observed that the father is not working hard, and he followed too.

Qaisarah: But like some people said, there may be a generation in the past that is poor but that should not be a barrier to success.

Teacher: But like what Irfan said, the child observed the father's laziness, so he grew up to become lazy too, so ...?

Qaisarah: Because that is his choice, he chooses it.

Alisya: But there are some people who comes from the poor generation, he can start from zero and he aspires to become rich and he tries. This is possible and there is no barrier.

Qaishah: Because he did not pursue higher education.

Amsya $r$ : Why didn't he?

Qaishah: Because he has no money.

Sofi : Why didn't he ask for a scholarship?

Amsyar: Ok I understand because he is poor but there are many poor people whose children got 8 As and were successful

Qaishah: I meant that he did not have the opportunity to get a good education

Teacher: What do you mean by not having the opportunity to get a good education?

Qaishah: Like in Sabah Sarawak, at the orang Asli place ...that do not speak Malay language well.

The deliberation that occurred in Lesson 17 indicates that students are empowered to decide on the course of the discussion without the teacher's influence. This element signifies that a community of inquiry offers its members the space to not just express their views freely, but also determine the direction and values that they are interested to learn and understand.

\section{Impartiality}

"Impartial inquiry pursues an investigation of a matter of importance in an open, self-corrective and contextualistic manner" (Lipman, 2003, p. 96). In the teaching of CCE, students need to be fair and consider all options given. Unbiased alternative or judgement chosen should be the result after taking into account all or majority's interest, not merely be based on personal preference.

The excerpt of Lesson 17 also illustrates the point of how students tried to be impartial when considering all factors that contributed to an issue. In this lesson, a few students criticised the poor for "being lazy", "not working hard enough" or "failed to grab the opportunities around them" to have a better life. However, they did not simply condemn the unfortunate ones but, view the issue objectively through constructive criticism. Even though students did not reach a 
consensus, they were able to identify the problem and show progress in understanding the issue from different angles. Their cumulative contributions were relevant and helped to reinforce one another's views, hence making it an engaging discussion.

\section{Thinking for Oneself}

When CCE students are taught to be open-minded and impartial, it does not mean that they need to let go their sense of 'individuality' and conform to the society's need and choice. Students need to "take pride in the originality of their responses" (Lipman, 2003, p. 97). Others' opinions need to be heard and respected and a good community of inquiry also allows its members to be different and hold on to their belief. In fact, students will learn that differences in society can complement each other, instead of dividing them apart, if it is viewed positively.

Lesson 17:

Teacher: What is the effect of obesity in society?

Ain : The train cannot fit them, other people cannot enter the train (problem to the public transport).

Haziq : Healthcare services. Your blood pressure cannot be measured by standard blood pressure machine.

Irfan : Increased deaths. Limited source of food.

Amsyar: I disagree with the point on limited of sources of food. I think Allah has created the world in a sufficient way.

Lesson 24:

Alisha: I prefer to give money directly to the disable people then paying the tax because sometimes the government used the money for other things and only allocate a small portion to them.

Nadrah: But paying tax is obligatory.

Khalis : With all the country's problems like $1 M D B$, I feel that it is better that we pay directly to them (disabled people).

Amsyar: I would like to know the examples of taxes. (Teacher explained examples of taxes and the distributions).

It is important to note that excerpts from lessons 17 and 24 show how students disagreed and persisted in their positions or views. Lesson 24 also shows an instance where students seek clarification from the teacher on a certain issue before deciding on their conclusion. 


\section{DISCUSSION AND CONCLUSION}

The seven elements of community of inquiry that were identified in the CCE class indicate that the community of inquiry is an effective platform for interaction between a learner and other capable peers and adults. Its scaffolding element will eventually lead to advanced learning. As CCE subject is meant to prepare students to become active and responsible citizens, the community of inquiry is the foundation that should be achieved. In this Zone of Proximal Development (ZPD), the community's interactions (in dealing with questions, assumptions, challenges, a quest for meaning, deliberations and shared cognition) can help students to imitate their capable peers. Classroom dialogue, and not a mere conversation, can be a perfect model for ZPD (Morehouse, 1999). This social aspect of learning is aligned with Dewey's (1960) theoretical and practical emphasis on communal and self-corrective inquiry.

The results also showed that students displayed the ability to communicate respectfully. The increased participation among the students mirrored their good sense of belonging in the lessons. A good philosophical discussion should entail many elements of the community of inquiry as proposed by Lipman. It does not necessarily contain all elements at once, but the intertwined elements of deliberations, impartiality, quest for meaning, challenging as a process, shared cognition and thinking for oneself; will make the classroom dialogue become more critical and enlightening. In the teaching of CCE using this approach, the researcher has seen the improvement in the classroom dialogue in which students were more willing to question and challenge one another, to voice their opinions and ideas clearly, to support or disagree freely, and to become more receptive in hearing the multiple or opposite opinions.

This finding is in accordance with previous research in Malaysia which reported positive outcomes of the implementation of the PI approach (Preece \& Adila, 2012; Hashim et. al, 2014; Hussien et. al, 2017; Wan Yusoff, 2018, Wan Yusoff, Hashim, Khalid, Hussien, \& Mohd Kamalludeen, 2018). The implementation of P4C in more than sixty other countries since the 1980s has shown an undeniable positive effect of PI worldwide. These studies also found that when students feel empowered, they claim ownership of their experiences of learning. Students' engagement in terms of behaviour, such as the seven elements of community of inquiry, and cognitive is crucial in their learning process (Skinner \& Belmont, 1993; Christenson, Reschly \& Wylie, 2012). In this particular study, the classroom discussions showed that students benefitted from their empowerment and became more responsible in the views and ideas that they shared. This is the aim of CCE i.e., to spark students' inquiry minds and habits by continuously questioning and engaging in the world. This type of meaningful learning can happen in a CCE subject with the help of PI approach.

To conclude, the study has presented how the development of a Community of Inquiry can benefit both students and teachers to become a better learning community. It is applicable and suitable to be used in the teaching of CCE classroom and subjects that aim to engage students in creating their own meanings in learning. It empowers students directly and indirectly, unearth their inner potentials, and most importantly improve their thinking skills. The use of dialogue in the community of inquiry also stimulates students' thinking. It gives 'life' to the process of learning. It prepares students to become good and active citizens. The 
students' arguments over common and contestable themes enables civic and citizenship concepts to be better understood and applied in their daily lives.

With the new development of CCE in Malaysia, where does the Philosophical Inquiry approach fit in? Although many prefer it to be a stand-alone subject, the possibility of integrating it across the selected subjects can be made successful if careful attention is given to its pedagogy. The limited time allocated for the new CCE module should therefore be used to conduct the lesson using the PI approach. Teachers should be trained to apply it so that good philosophical discussions can be conducted in the classroom. Let it be the time allocated for students to practice their thinking and social skills. Allow the classroom agenda to be maneuvered by its own community of inquiry. Empower our students to discuss topics that are relevant to them even if the teachers help prepare the materials. Remind teachers to take positions as facilitators and give autonomy to students to own their lessons. Let disagreements and different perspectives be shared in a mutual and respectful manners. Together, all these elements will result in a conducive and productive CCE learning experience, consequently assisting in the realization of the aspirations of Shift 3 of the MEB.

\section{Acknowledgment}

This study was supported by the Ministry of Higher Education, Malaysia Fundamental Research Grant Scheme FRGS13-011-0252 


\section{REFERENCES}

Alivernini, F., \& Manganelli, S. (2011). Is there a relationship between openness in classroom discussion and students' knowledge in civic and citizenship education? Procedia-Social and Behavioral Sciences, 15, 3441-3445.

Bandu, S. H., Awang, M. M., \& Ahmad, A. R. (2017). Attributes for Multi-Ethnic Students' Acceptance towards the Cultivation of the Implementation of Citizenship Values in Secondary School. International Journal of Academic Research in Business and Social Sciences, 7(3), 495-503.

Cam, P. (1995) Thinking Together: Philosophical Inquiry in the Classroom (Sydney, Hale \& Iremonger).

Christenson, S. L., Reschly, A. L., \& Wylie, C. (Eds.). (2012). Handbook of research on student engagement. Springer Science \& Business Media.

Dewey, J. (1933). How We Think. New York: Heath \& Co.

Dewey, J. (1960). Philosophies of freedom. On experience, nature and freedom.

Dewey, J. (1972). The Early Works, 1882-1898, Volume 5. Southern Illinois University Press, 1975.

Fisher, R. (2003) Teaching Thinking: Philosophical enquiry in the classroom, 2nd ed. London: Continuum.

Ghaemi, F. (2017). The impact of inquiry-based learning approach on critical thinking skill of EFL students. EFL Journal, 2, (2), 89-102. doi: http://dx.doi.org/10.21462/eflj.v2i2.38

Hannam, P., \& Echeverria, E. (2009). Philosophy with teenagers: Nurturing a moral imagination for the 21 st century. A\&C Black.

Hashim, R. Hussien, S. and Juperi, J. A. (2014) The hikmah (wisdom) program: a philosophical inquiry for the teaching of Islamic education in Malaysia. In S. Buang, P. G-C. Liew, eds. Muslim Education in the 21st Century: Asian perspectives. London: Routledge, pp. 125141.

Hussien, S., Hashim, R. and Mohd. Mokhtar, N. A. (2017). Hikmah pedagogy: Promoting open-mindedness, tolerance and respect for others' religious views in classrooms. In D. R. Wielzen, I. T. Avest (Eds.) Interfaith education for all. Rotterdam: Sense Publishers, pp. 97-106.

Kennedy, D. (2012). Lipman, Dewey, and Community of philosophical inquiry. Education and Culture, 28 (2), 36-53

Lee, J. W. S. (2011). Structure and Agency: A Comparison of Youth Learning of Citizenship in Taipei and Calgary. In Citizenship Pedagogies in Asia and the Pacific. Dordrecht: Springer, pp. 81-105.

Lipman, M. (2003) Thinking in Education. 2nd ed. Cambridge: Cambridge University Press. 
Mahmood, H. (2014). Civics and citizenship education in Malaysia: The voice of micro policy enactors. (Doctoral Thesis, Cardiff University). Retrieved from http://orca.cf.ac.uk/id/eprint/69576.

Malay Mail. (2019, August 13). Education minister: Civic education to be introduced in Malaysia schools in integrated, holistic manner. https://www.malaymail. com/news/malaysia/2019/08/13/education-minister-civics-education-to-be-introducedin-integrated-holistic/1780227

McCall, C. (2009). Transforming thinking. Philosophical Inquiry in the Primary and Secondary Classroom. London \& New York: Routledge.

Millett, S., \& Tapper, A. (2012). Benefits of collaborative philosophical inquiry in schools. Educational Philosophy and Theory, 44(5), 546-567.

Morehouse, R. (1999, July). Philosophical inquiry in a classroom situation: A case study with broader implications. Paper delivered at 5th International Conference on Philosophy in Practice, Wadham College, Oxford.

PADU - Education Performance and Delivery Unit, Ministry of Education website. Retrieved from https://www.padu.edu.my/about-the-blueprint/\#shifts

Peck, C. (2009). Peering through a kaleidoscope: Identity, historical understanding and citizenship in Canada. Citizenship Teaching and Learning, 5 (2), 62-75.

Preece, A.S \& Juhasni, A. J. (2014). Philosophical inquiry in the Malaysian educational system-reality or fantasy? Analytic Teaching and Philosophical Praxis, 35 (1), 26-38.

Schulz, W., Fraillon, J., Ainley, J., Losito, B., \& Kerr, D. (2008). International Civic and Citizenship Education Study: Assessment framework. Amsterdam, The Netherlands: International Association for the Evaluation of Educational Achievement (IEA).

Skinner, E. A., \& Belmont, M. J. (1993). Motivation in the classroom: Reciprocal effects of teacher behavior and student engagement across the school year. Journal of educational psychology, 85 (4), 571-581

Smallhorn, M., Young, J., Hunter, \& Burke Da Silva, K. (2015). Inquiry-based learning to improve student engagement in a large first year topic. Student Success. 6 (2), 65-71

Splitter, L., \& Sharp, A. M. (1995). Teaching for Better Thinking (Melbourne, Australian Council for Educational Research).

Sriarunrasmee, J., Suwannatthachote, P. \& Dachakupt, P. (2015). Virtual field trips with inquiry learning and critical thinking process: a learning model to enhance students' science learning outcomes. Procedia - Social and Behavioral Sciences 197, 1721 - 1726. doi: 10.1016/j.sbspro.2015.07.226

Striano, M. (2011). The community of philosophical inquiry as a social and cognitive matrix, Childhood \& Philosophy, 7 (13), $91-102$.

Torney-Purta, J., Richardson, W., \& Barber, C. (2005). Teachers' educational experience and confidence in relation to students' civic knowledge across countries. Citized 1 (1), 32-57. 
UNESCO (2009) Thinking for the Future: An action plan for the promotion of philosophy teaching in Asia and the Pacific. Retrieved from http://www.unescobkk.org/ fileadmin/ user_upload/shs/Philosophy/ aspacactionphilpla ndraft5.pdf

Vygotsky, L. S. (1978). Mind in society: The development of higher psychological processes. Cambridge, MA: Harvard University Press.

Wan Yusoff, W. M. (2018). The Impact of Philosophical Inquiry Method on Classroom Engagement and Reasoning Skills of Low Achievers. Journal of Curriculum and Teaching, 7(1), 135-146.

Wan Yusoff, W. M., Hashim, R., Khalid, M., Hussien, S., \& Mohd Kamalludeen, R. (2018). The Impact of Hikmah (Wisdom) Pedagogy on 21st Century Skills of Selected Primary and Secondary School Students in Gombak District Selangor Malaysia. Journal of Education and Learning, 7 (6), 100-110.

Wilks, S. (1995). Critical \& creative thinking: Strategies for classroom inquiry. USA: Heinemann Educational Publishers.

Zulkifli, H., \& Hashim, R. (2019). Moral reasoning stages through Hikmah (Wisdom) pedagogy in Moral Education. International Journal of Academic Research in Progressive Education and Development, 8 (4), 886 - 899.

Zulkifli, H., Razak, K.A., \& Mahmood, M. R. (2018). The Usage of ADDIE Model in the Development of a Philosophical Inquiry Approach in Moral Education Module for Secondary School Students. Creative Education, 9, 2111-2124. https://doi. org/10.4236/ce.2018.914153 